Elżbieta Jastrzębska

Uniwersytet Zielonogórski

\title{
PRZYGOTOWANIE DO TWÓRCZOŚCI PEDAGOGICZNEJ W KSZTAŁCENIU WSTĘPNYM NAUCZYCIELI JĘZYKÓW OBCYCH
}

\author{
Preparing foreign language teacher trainees in initial training for \\ creativity in teaching
}

Creativity in teaching in the subject literature can be divided into three categories: the creative process, the product and the support of the development of creative activity in students. Not only is creativity important for the teacher today but also it is an essential part of his or her professional identity. In XXI century pedeutology [a branch of educational theory] the vision is of an open-minded and autonomous teacher, a reflective practitioner who is prepared to create his or her own new strategies to function in educational situations which are constantly changing. This educator effectively supports the personal development of the student and their process of learning. For this reason, creativity in teaching should also be one of the principal objectives of the professional training of the foreign language teachers, which in turn poses important questions. The notion of creativity in teaching, its scope and how it can be prepared for during the academic training of the foreign language teachers are the subjects of the article.

„Ludzka osoba jest osobowością potencjalną, a więc taką, która poprzez swe akty doskonali się, buduje i spełnia, czyli dochodzi do pełni."

Mieczysław A. Krapiec 


\section{Twórczość w edukacji a twórczość nauczyciela}

\subsection{Prekursorzy i współcześni}

Potrzebę twórczej edukacji widzieli już wielcy przedwojenni pedagogowie, m.in. Henryk Rowid, Zygmunt Mysłakowski, Jan Władysław Dawid, Stefan Szuman, Helena Radlińska. Podkreślają oni szczególną rolę nauczyciela, mówiąc o jego talencie pedagogicznym, utożsamianym często z twórczym działaniem lub z odpowiednimi uwarunkowaniami osobowościowymi. Stefan Szuman zakłada, że to, co nauczyciel ma najlepszego do ofiarowania, to bogactwo jego osobowości, przy czym liczy się również sposób, w jaki tego dokonuje (Okoń, 2009: 243-244). W ten nurt refleksji wpisuje się Jan Władysław Dawid, swoim krótkim, ale znaczącym dziełem $O$ duszy nauczycielstwa (1932), w którym podkreśla emocjonalny i duchowy wymiar relacji nauczyciela z wychowankami. Henryk Rowid tworzy natomiast koncepcję szkoły twórczej ${ }^{1}$ będącej polską syntezą współczesnych mu założeń Nowego Wychowania. Szkoła ta ma wyzwalać twórczy potencjał, aktywność i samodzielność dziecka, które staje się centrum działania pedagogicznego. W tej koncepcji rola nauczyciela i jego właściwe kształcenie są bardzo istotne. Rowid jest pierwszym polskim pedagogiem, który przywołuje pojęcie twórczego nauczyciela, cechującego się odpowiednimi zdolnościami, intuicją i taktem pedagogicznym (Stankiewicz, 2002).

Przeświadczenie, iż twórczość jest immanentną właściwością każdego człowieka stoi u źródła współczesnego pankreacjonizmu oraz jego pedagogicznej wersji (Jastrzębska, 2011: 20). Pedagogiczny kreacjonizm formułuje na nowo ideę edukacji twórczej, która obejmuje trzy ważne szczegółowe koncepcje, a mianowicie: 1) szkoły jako organizacji twórczej, 2) twórczego nauczyciela, 3) twórczego ucznia (Schulz, 1996: 9-32).

Syntezę tych koncepcji przedstawia schemat 1.

\footnotetext{
${ }^{1}$ Najważniejsze publikacje H. Rowida na ten temat: Szkoła twórcza (1926), Psychologia pedagogiczna i Podstawy i zasady wychowania (1946).
} 
Przygotowanie do twórczości pedagogicznej w kształceniu wstępnym nauczycieli...

\begin{tabular}{|c|c|c|c|}
\hline \multicolumn{4}{|c|}{ Talent pedagogiczny, utożsamiany } \\
\hline \multicolumn{2}{|c|}{$\frac{\text { z twórczym działaniem }}{- \text { Z. Mysłakowski }}$} & \multicolumn{2}{|c|}{$\frac{\text { z bogactwem osobowości }}{\text { - S. Szuman, J.W. Dawid }}$} \\
\hline \multicolumn{4}{|c|}{ Szkoła twórcza - H. Rowid } \\
\hline \multicolumn{2}{|c|}{$\begin{array}{c}\text { Nauczyciel twórczy - intuicja } \\
\text { i takt pedagogiczny }\end{array}$} & \multicolumn{2}{|c|}{$\begin{array}{l}\text { twórczy potencjał, aktywność } \\
\text { i samodzielność dziecka }\end{array}$} \\
\hline \multicolumn{4}{|c|}{ Edukacja twórcza (R. Schulz) } \\
\hline $\begin{array}{c}\text { 1) szkoła jako } \\
\text { organizacja twórcza }\end{array}$ & $\begin{array}{l}\text { 2) twó } \\
\text { (twórczo }\end{array}$ & $\begin{array}{l}\text { Iczyciel } \\
\text { gogiczna) }\end{array}$ & 3) twórczy uczeń \\
\hline
\end{tabular}

Schemat 1: Wybrane koncepcje twórczego nauczyciela w pedagogice polskiej. (Źródło: opracowanie własne).

Wymiar osobowościowy w kształceniu nauczycieli związany z imperatywem rozwijania twórczości ucznia oraz specyfiką zawodu-powołania jest również obecny w dyskursie pedagogicznym XXI wieku. Wyzwaniem czasu określa się „poszukiwanie koncepcji twórczego rozwoju nauczyciela, twórczej edukacji na miarę potrzeb współczesnej szkoły [...]" (Koć-Seniuch, 2003: 95). Szkoła przyszłości jawi się jako instytucja zintegrowana i otwarta, pełniąca funkcję emancypacyjną i zachęcająca nauczycieli do twórczości (Kupisiewicz, 2006: 118-122). Jako zasadniczą przyczynę tego stanu rzeczy wielu znawców przedmiotu wskazuje zmianę filozofii edukacyjnej z adaptacyjnej na krytyczno-kreatywną. Najważniejszym jej wyznacznikiem jest odwrócenie hierarchii celów edukacyjnych, gdzie wspomaganie rozwoju osobowego uczniów znajduje się na pierwszym miejscu, a przekazywanie wiedzy na ostatnim (Lewowicki, 2007: 113-114). Zmiana ta przyczynia się znacznie do wzrostu znaczenia orientacji humanistycznej w kształceniu nauczycieli.

\subsection{Natura działania pedagogicznego a twórczość nauczycieli}

Literatura pedeutologiczna ukazuje ambiwalencję roli zawodowej nauczyciela, „człowieka uwikłanego w sprzeczności [...], w rozwiązywanie złożonych problemów wychowawczych i dydaktycznych" (Kwiatkowska, 2008: 200201), na które brak gotowych recept. Najważniejsze z przeżywanych przez nauczyciela dylematów wynikających z natury działania pedagogicznego, to jego fizyczne i psychologiczne umiejscowienie między: 
- osobą a społeczeństwem (a więc między autonomią a socjalizacją);

- jednością a różnorodnością;

- zależnością (podporządkowaniem) a autonomią;

- niezmiennością a zmiennością ;

- otwarciem a zamknięciem;

- harmonią a konfliktem;

- równością a różnorodnością uczniów (zainteresowań, potrzeb, zdolności, typów inteligencji, preferencji sensorycznych) (Perrenoud, 1999: 25-28).

Ta złożoność i specyfika procesów edukacyjnych oraz konieczność realizacji naczelnego zadania edukacyjnego, jakim jest wspomaganie rozwoju osobowego ucznia, wymagają nowych postaw i kompetencji typu kreatywnego od każdego nauczyciela. Ma on być przygotowany do poszukiwania i tworzenia własnych strategii nauczania oraz wychowania, do różnicowania swojego działania pedagogicznego, ciągłego poddawania go w wątpliwość i stawiania sobie ważnych pytań (Perrenoud, 1999; Zawadzka, 2004; Łobocki, 2005; Richer, 2011).

Wszechstronny rozwój nauczyciela staje się więc nie tylko priorytetem kształcenia zawodowego, ale również niezmiernie ważnym warunkiem skutecznej edukacji szkolnej.

\section{Twórczość pedagogiczna jako wytwór i jako proces}

O twórczości pedagogicznej mówi się na przestrzeni ostatnich lat wiele, zwłaszcza w kontekście działań związanych bezpośrednio z praktyką edukacyjną, z programowaniem materiału dydaktycznego, z modyfikacją, modernizacją lub kreowaniem nowych rozwiązań: metodycznych, wychowawczych i organizacyjnych (Kwaśnica, 2003; Kupisiewicz, 2006; Okoń, 2009). Jest ona coraz częściej rozpatrywana jako twórczość codzienna, ${ }^{3}$ która jest cechą stałą i wynika z potrzeby rozwoju zawodowego (Łączyk, 2011: 230).

W przywoływanej wcześniej koncepcji R. Schulza pojawia się pojęcie twórczości pedagogicznej obejmującej: 1) praktykę kształcenia i wychowa-

\footnotetext{
2 „Éduquer ou instruire c'est permettre à l'apprenant de changer sans perdre son identité, c'est concilier l'invariance et le changement" - Edukować lub kształcić to pozwolić uczniowi zmieniać się bez utraty jego tożsamości, to pogodzić niezmienność ze zmiennością (Perrenoud, 1999: 27, tłum. autorki).

${ }^{3}$ To pojęcie zostało rozpowszechnione w literaturze naukowej przez Ruth Richards, Marca A. Runco i Annę Craft. W piśmiennictwie polskim z terminem tym można spotkać się w pracach Edwarda Nęcki i Krzysztofa J. Szmidta (ModrzejewskaŚwigulska, 2009: 148-149).
} 
nia, 2) nowoczesną pracę pedagogiczną, 3) działalność innowacyjną, 4) samorealizację zawodową nauczycieli (za: Ekiert-Oldroyd, 2003: 141).

Nestor współczesnej polskiej pedagogiki, Wincenty Okoń (2004: 430), podkreśla rolę racjonalizatorstwa i nowatorstwa pedagogicznego jako etapu wstępnego twórczości pedagogicznej. W tej perspektywie, twórczość pedagogiczna może być: 1) wytworem (np. autorski program nauczania czy plan działań wychowawczych, inwentarz oryginalnych ćwiczeń, scenariusz zajęć lekcyjnych, etc.) lub 2) procesem (nowatorskie formy realizacji zadania: stosowanie twórczych technik pracy na lekcji, praca nauczyciela nad samodoskonaleniem, nad formami interakcji, etc.).

Wymiar procesualny twórczości pedagogicznej ma duże znaczenie w zakresie działalności wychowawczej. W literaturze przedmiotu wymienia się ciekawe formy współpracy z uczniami, z kolegami nauczycielami, z rodzicami, ze środowiskiem, dialog, negocjacje, tworzenie odpowiednich sytuacji i zadań wychowawczych, zarządzanie zespołem klasowym, realizację większych (szkolnych, międzyszkolnych, międzynarodowych) lub mniejszych (klasowych) projektów, które wymagają otwartej twórczej postawy i kompetencji kreatywnych (Perrenoud, 1999: 80; Petkowicz, 2005: 203-205).

Mówiąc o twórczości pedagogicznej jako procesie, nie można nie przywołać pojęcia refleksji definiowanej jako zdolność do analizowania własnej praktyki edukacyjnej, która występować może w trzech momentach: 1) przed nauczaniem (jako działanie antycypacyjne, podczas planowania czynności edukacyjnych), 2) podczas nauczania (jako działanie regulacyjne), 3) po nauczaniu (jako ewaluacja dokonanych działań) (Correa Molina, E. i in., 2010: 140).

Na znaczenie refleksyjnej praktyki w zawodzie nauczyciela i jej związek z umiejętnościami badawczymi oraz zdolnością do autokreacji i tworzenia innowacyjnych rozwiązań edukacyjnych, kładzie nacisk wielu znawców przedmiotu, zarówno z zakresu glottodydaktyki, jak i pedagogiki (Palka, 2003; Zawadzka, 2004; Wilczyńska, 2009; Dylak, 2010). Innowacje edukacyjne są najczęściej rozumiane jako próba optymalizacji procesu kształcenia i wychowania poprzez wywoływanie zmian, wymagające refleksji nad działaniem i w działaniu oraz samodzielności poznawczej (a nawet badawczej).

Ze współczesnej literatury przedmiotu wyłania się trójfazowa, procesualno-atrybutywna koncepcja twórczości pedagogicznej (refleksja, badania w działaniu, innowacje), którą przedstawia schemat 2. 


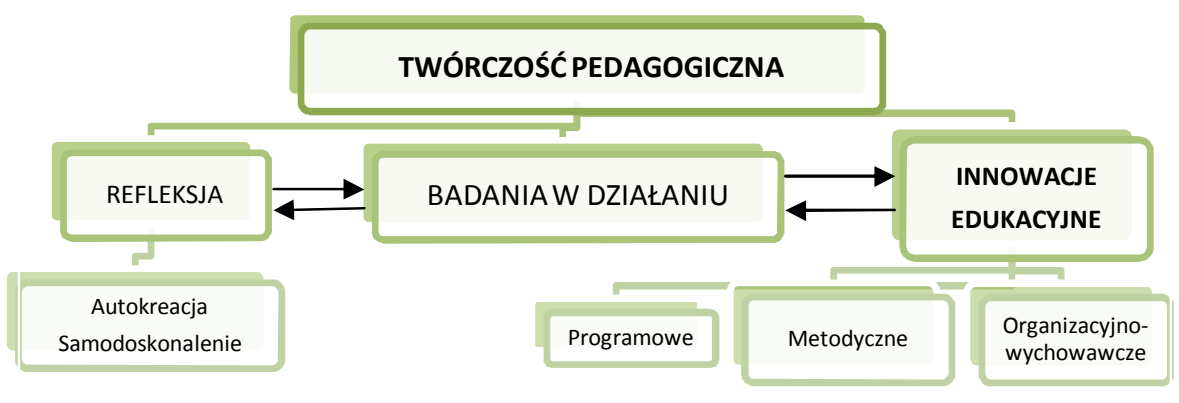

Schemat 2: Trójfazowa koncepcja twórczości pedagogicznej. (Źródło: opracowanie własne).

Ciekawą definicję twórczości pedagogicznej przedstawia Stanisław Popek (za: Sikora, 2009: 130-131) wskazując na jej trzy aspekty: 1) proces twórczy, 2) wytwór, 3) wspieranie rozwoju postawy twórczej uczniów. Przez ostatni wymiar uwypukla centralną pozycję ucznia i jego podmiotowość.

Moim zdaniem jednak, aby ta definicja była pełna, oprócz szeroko pojętego wymiaru procesualnego (proces twórczy, wspieranie postawy twórczej uczniów) oraz atrybutywnego (wytwór i jego cechy), należałoby uwzględnić w niej jeszcze wymiar personologiczny, dotyczący postaw i cech osoby nauczyciela-twórcy, jego savoir-être, „jego woli działania i gotowości ciągłego poszukiwania" (Richer, 2011: 75). "Wymiar ten będzie miał istotne znaczenie w ujęciu twórczości pedagogicznej jako kompetencji.

\section{Twórczość pedagogiczna jako kompetencja}

Mówiąc o kompetencji zawodowej nauczyciela, definiuje się ją zawsze w powiązaniu z działaniem i umiejętnością tegoż działania. Składa się z wiedzy deklaratywnej, umiejętności proceduralnych, umiejętności ich mobilizacji, specyficznych uwarunkowań osobowych. Jest więc ona nie tyle stanem, co procesem (Le Boterf, 1994: 43; Coiduras i Carrera, 2010: 98-100).

Wielu znawców przedmiotu wymienia twórczość jako jedną z najważniejszych kompetencji zawodowych nauczyciela obejmującą przede wszystkim postawy i cechy osobowe umożliwiające wspieranie wszechstronnego rozwoju ucznia, skuteczne działanie edukacyjne i stawanie się nauczycielem

\footnotetext{
${ }^{4} \mathrm{~W}$ oryginale : „Dans l'enseignement des langues, le vouloir agir a à voir avec un refus de l'enseignant de se figer dans la routine, avec une quête incessante de renouvellement, une volonté de se surprendre par sa capacité d'innover."
} 
(Wróblewska, 2011; Targońska, 2009; Sajdak, 2008; Gaś, 2001). Mówi się o aktywności podmiotowo-sprawczej, o kompetencji kreatywnej, kompetencjach kreatywnych lub innowacyjno-kreatywnych, które polegają na umiejętności stymulowania kreatywności i autonomii uczniów, twórczym rozwiązywaniu problemów, krytycznym myśleniu, niestandardowości działania (Wróblewska, 2011; Zawadzka, 2004).

Twórczość pedagogiczna przedstawia się w tym ujęciu jako kompetencja transwersalna, niezbędna do właściwego funkcjonowania wszystkich innych umiejętności profesjonalnych nauczyciela ${ }^{5}$, do refleksji nad własną praktyką pedagogiczną, do prowadzenia badań w działaniu, do podejmowania działań innowacyjnych, a także do samodoskonalenia i własnego rozwoju (Zawadzka, 2004: 299-303). W moim przekonaniu, najważniejszym jej komponentem jest szeroko rozumiana postawa twórcza ${ }^{6}$, którą powinno się rozwijać w kształceniu uniwersyteckim nauczycieli. Jej trójwymiarową strukturę wizualizuje poniższy schemat.

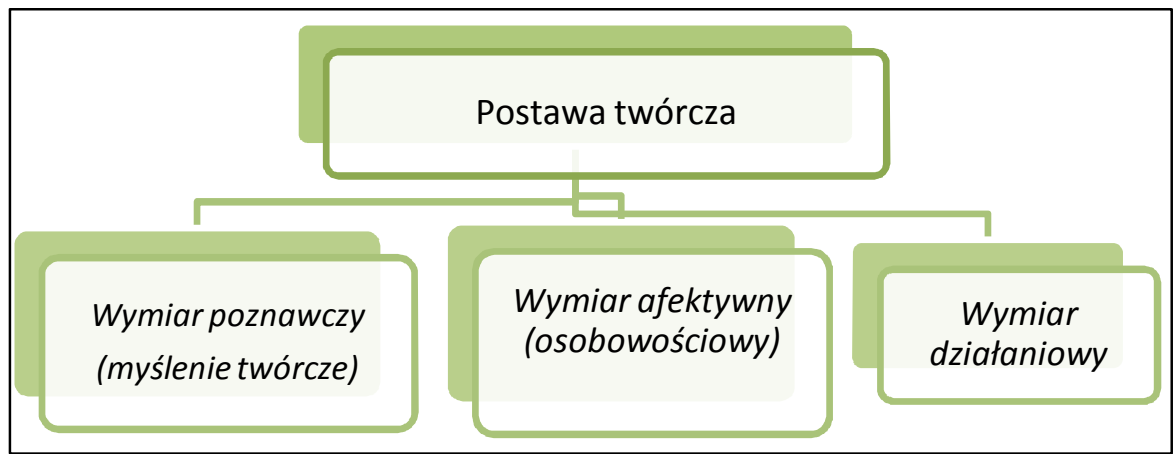

Schemat 3: Struktura postawy twórczej. (Źródło: Szmidt, 2007: 152-153).

\section{Edukacja twórcza w kształceniu nauczycieli języków obcych jako ich przygotowanie do twórczości pedagogicznej}

W związku z nowymi wyzwaniami edukacji XXI w., zachodzi konieczność zdefiniowania na nowo roli zawodowej nauczycieli i zasadniczych zmian w kształce-

\footnotetext{
${ }^{5}$ Różnie nazywanych i klasyfikowanych w literaturze przedmiotu, ale zawsze streszczających się w trzech głównych kategoriach (kompetencje przedmiotowe, k. metodyczne, k. psychopedagogiczne).

6 "Jest to zespół dyspozycji poznawczych, emocjonalno-motywacyjnych (afektywnych) i behawioralnych (działaniowych), który umożliwia jednostce reorganizowanie dotychczasowych doświadczeń, odkrywanie i konstruowanie czegoś dla niej nowego i wartościowego." (Szmidt, 2007: 159).
} 
niu nauczycieli. Literatura przedmiotu postuluje wielostronność kształcenia, które miałoby integrować trzy odmienne tradycje pedeutologiczne, a mianowicie: pierwszą, zorientowaną na rozwój osobowości, drugą, kładącą nacisk na funkcjonowanie społeczne oraz trzecią, skoncentrowaną na kształceniu pedagogicznych i merytorycznych kompetencji nauczycieli (Gnitecki, 2002: 54).

Współczesna pedeutologia inspirowana przez psychologię humanistyczną za swój podstawowy cel uważa wsparcie studenta w procesie stawania się nauczycielem, zarówno w budowaniu jego tożsamości zawodowej, jak i w jego ogólnym rozwoju osobowym (Kwiatkowska, 2005: 54-55; Kwaśnica, 2003: 293). Włączenie edukacji twórczej do programu nauczycielskich studiów zawodowych ułatwiłoby realizację tego ważnego zadania.

Moim zdaniem, kształcenie wstępne nauczycieli języków obcych już na etapie licencjatu winno przygotowywać do twórczości pedagogicznej. Jest to przedsięwzięcie niełatwe, ale możliwe do urzeczywistnienia rozmaitymi sposobami. Dobrym rozwiązaniem byłoby włączenie do bloku przedmiotów psychopedagogicznych obowiązkowych zajęć z pedagogiki lub dydaktyki twórczości (np. w wymiarze 30 godz.). Innym sposobem mogłoby być poświęcenie kilku godzin ćwiczeń z pedagogiki ogólnej na lekcje twórczości oraz zrealizowanie kilkunastogodzinnego modułu edukacji kreatywnej w ramach dydaktyki szczegółowej.

Jeśli chodzi o wykorzystanie zajęć dydaktyki szczegółowej, to jej program nic na tej modyfikacji nie straci, wręcz przeciwnie, zostanie wzbogacony, gdyż strategie psychodydaktyki twórczości, a zwłaszcza techniki rozwijania postawy twórczej, nadają się doskonale do zastosowania na lekcji języka. Studenci, ucząc się twórczości, równocześnie wdrażają się do kreatywnego nauczania/uczenia się języka obcego. Jedną z prac projektowych wliczanych do oceny końcowej z ćwiczeń z dydaktyki szczegółowej mogłoby być jakieś praktyczne zadania twórcze, np. przygotowanie scenariusza lekcji języka z wykorzystaniem technik kreatywnych czy też zestawu ćwiczeń twórczych na rozwijanie danej sprawności językowej (mówienia lub pisania). Można również zaproponować studentom realizację chociaż jednego większego projektu kreatywno-dydaktycznego w semestrze. Mogą to być warsztaty językowe, ludyczne czy twórcze dla młodzieży szkolnej. Bardzo dobrym przygotowaniem do twórczości pedagogicznej jest udział studentów w organizacji wydarzeń językowo-kulturowych (Dni Języka i Kultury, festiwale i konkursy) oraz w różnego typu przedsięwzięciach naukowych (studenckie konferencje i seminaria czy projekty badawcze). Starajmy się także uczyć twórczości $w$ działaniu na zajęciach z praktycznej nauki danego języka, poprzez stosowanie kreatywnych strategii do rozwijania sprawności językowych (Jastrzębska, 2011). 


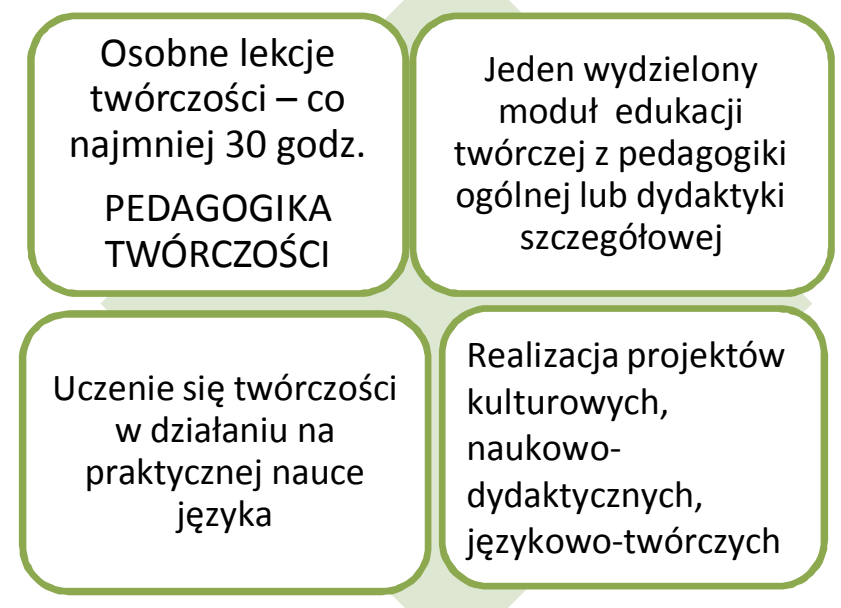

Schemat 4: Sposoby realizowania edukacji twórczej w kształceniu nauczycieli języków obcych (Źródło: opracowanie własne).

W nowym, zmodyfikowanym według $\mathrm{KRK}^{7}$, programie studiów filologicznych, w ramach przedmiotu do wyboru istnieje możliwość przygotowania propozycji choćby 30 godzin ćwiczeń w zakresie edukacji twórczej. Warto również zadbać o to, aby zajęciom praktycznym treningu kreatywności towarzyszyło wdrażanie studentów do autoanalizy w celu uświadomienia sobie przez nich własnych postaw i działań. Polega ono przede wszystkim na samoobserwacji połączonej z autorefleksją stymulowaną odpowiedziami na proponowane przez prowadzącego pytania ankietowe, kwestionariusze czy testy kreatywności.

\section{Przykład praktyki: rozwijanie postawy twórczej studentów filologii romańskiej UZ}

Nie umniejszając znaczenia wiedzy deklaratywnej na temat twórczości, którą uwzględniam w zakresie podstawowym, w swoim programie zajęć proponuję praktyczne zajęcia treningu kreatywności (Jastrzębska, 2009) rozumianego jako system ćwiczeń psychoedukacyjnych, indywidualnych lub grupowych służących rozwijaniu wielowymiarowej postawy twórczej (myślenie twórcze, uwarunkowania osobowościowe, działanie). Istnieje sporo pozycji w literaturze przedmiotu proponujących tego typu ćwiczenia, ja korzystam przede wszyst-

\footnotetext{
${ }^{7}$ Krajowe Ramy Kwalifikacji
} 
kim z koncepcji twórczych operacji poznawczych Edwarda Nęcki (2005), lekcji twórczości i treningu kreatywnego Krzysztofa J. Szmidta (2007, 2008), ogólnie dostępnych testów twórczości Joya Paula Guilforda i Ellisa Paula Torrance’a.

Poniższy schemat przedstawia typy myślenia twórczego rozwijane na prowadzonych przeze mnie zajęciach z edukacji twórczej.

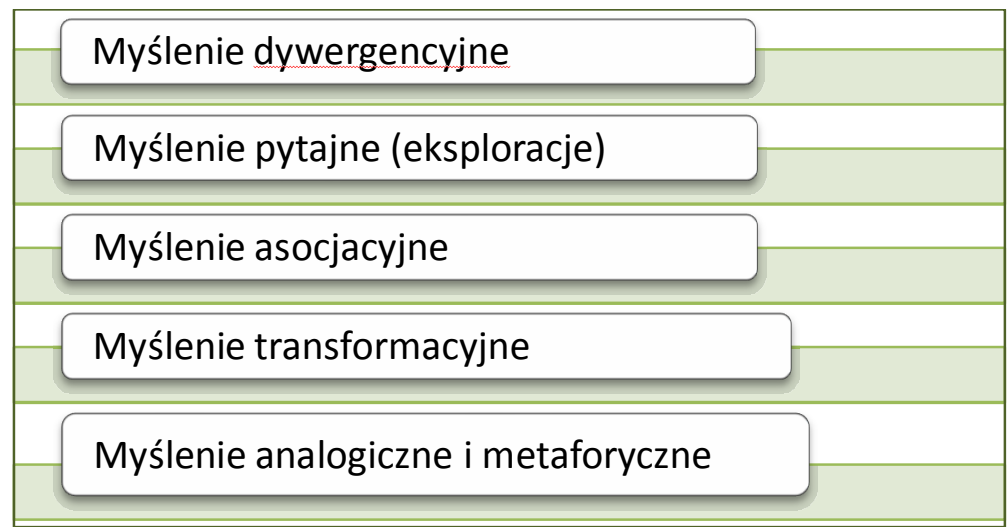

Schemat 5: Typy myślenia twórczego rozwijane poprzez trening kreatywności. (Źródło: opracowanie własne).

Techniki dywergencyjne (hipotezy, spekulacje, przypuszczenia, testy niezwykłych zastosowań, kategoryzacje) stanowią podstawę treningu kreatywności i nadają się wspaniale do twórczej rozgrzewki, rozwijając tak ważne do generowania pomysłów czynniki jak: płynność, giętkość i oryginalność. Skutecznym i bardzo lubianym przez uczestników zadaniem jest stawianie niezwykłych hipotez, np.: odpowiedzi na pytanie typu: Co by było gdyby...?, podawanie możliwych przyczyn lub następstw danego wydarzenia czy sytuacji, wyobrażanie sobie wzajemnych relacji między wskazanymi postaciami. Czwarty czynnik myślenia dywergencyjnego, a mianowicie percepcja problemu, wiąże się ściśle z myśleniem pytajnym (eksploracjami), a zwłaszcza gotowością do dziwienia się. Ciekawym ćwiczeniem jest tutaj wymyślanie tzw. dziecinnych pytań i poszukiwanie na nie odpowiedzi.

W następnej kolejności ćwiczymy techniki myślenia asocjacyjnego, polegające na kojarzeniu i łączeniu często odległych pojęć oraz twórcze transformacje „wybranych właściwości jakiejś rzeczy, procesu lub stanu” (Szmidt, 2008: 151), np. ulepszenia, powiększania, uzupełnienia, eliminacje. Schemat 6 przedstawia wybrane strategie asocjacyjne, stosowane często na zajęciach i lubiane przez studentów. 


\begin{tabular}{|l|l|l|}
\hline \multicolumn{3}{|c|}{ I. Kojarzenie automatyczne idei (pojęć) } \\
\hline 1. Gwiazda skojarzeń & 2. Konstelacja słów & 3. Łańcuch skojarzeń \\
\hline \\
\hline II. Kojarzenie pojęć „przemyślane” \\
\hline 4. Sieć skojarzeń & $\begin{array}{r}\text { 5. Łańcuchy } \\
\text { alternatywne }\end{array}$ & $\begin{array}{c}\text { 6. Trigram-odległe } \\
\text { skojarzenia }\end{array}$ \\
\hline
\end{tabular}

Schemat 6: Wybrane techniki asocjacyjne. (Źródło: opracowanie własne).

Gwiazda skojarzeń polega na podaniu jak największej ilości swobodnych skojarzeń do jednego centralnego pojęcia, natomiast konstelacja słów wymaga ich uporządkowania i podziału na gwiazdozbiory tematyczne. Z kolei tworzenie tańcucha skojarzeń to stopniowe oddalanie się od idei początkowej przez wprowadzanie kolejnych skojarzeń do ostatniego podanego słowa np. radość -dzieci-szkoła - nauka - kłopoty.

Myślenie analogiczne i metaforyczne różni się od poprzednich typów myślenia, gdyż jego źródłami inspiracji są emocje, intuicje, marzenia (Jastrzębska, 2011: 182). Zadania twórcze oparte na czterech rodzajach analogii: osobistej, prostej, symbolicznej i fantastycznej rozwijają afektywny i działaniowy wymiar postawy twórczej. Strategie projekcyjne (identyfikacje i personifikacje) oraz techniki dramowe uczą empatii, otwartości, rozumienia inności. Ćwiczenia oniryczne, jak np. ukierunkowane marzenia (R.E.D. ${ }^{8}$ ) czy tworzenie tekstów poetyckich inspirowanych cytatem, przysłowiem, metaforą lub słuchaną muzyką, rozwijają wyobraźnię, zdolność ekspresji, myślenie symboliczne.

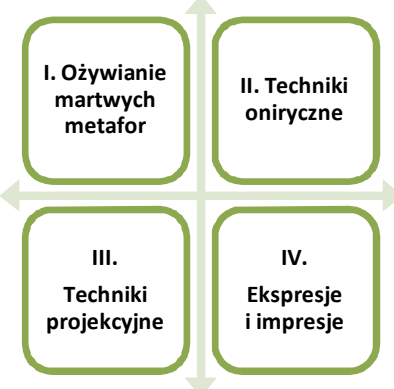

Schemat 7: Wybrane kategorie technik analogicznych i metaforycznych. (Źródło: opracowanie własne).

${ }^{8}$ R.E.D. to skrót francuskiej nazwy tej techniki:- rêve éveillé dirigé. 
Ważną rolę w rozwijaniu postawy twórczej, zarówno w wymiarze kognitywnym, jak i działaniowym oraz osobowościowym spełnia twórcze rozwiązywanie problemów. Strategia ta dysponuje wieloma metodami i programami, z których najbardziej znane to synektyka W. Gordona, Creative Problem Solving (CPS) D. J. Treffingera, B.K. Dorvala i S.G. Isaksena, model inkubacyjny E.P. Torrance'a i Cognitive Research Trust (CoRT) E. de Bono, oparty na różnych technikach myślenia lateralnego. W naszym zielonogórskim programie edukacji twórczej posługujemy się często mniej znaną, ale niemniej skuteczną koncepcją twórczego rozwiązywania problemów, pochodzącą z francuskiego obszaru językowego, a mianowicie podejściem analogicznym Paula Cussona (1993). Po określeniu sytuacji (problemu, pytania) przeprowadza się szczegółową analizę jej negatywnych aspektów (braków, wad), tzw. analizę defektologiczną. Podejście analogiczne Paula Cussona wykorzystuje metafory w formie oksymoronu oraz analogie bezpośrednie do rozwiązania problemu lub naprawienia/ulepszenia sytuacji. Zasadniczym elementem odróżniającym tę koncepcję od innych jest to, że etap poszukiwania rozwiązań znajduje się zawsze na końcu.

Zadania TRP ${ }^{9}$ wykorzystują wszystkie typy myślenia twórczego, ale wymagają też użycia myślenia konwergencyjnego. Rozwijają umiejętność konceptualizacji, analizy i syntezy, uczą argumentowania, negocjacji, dokonywania wyborów, współpracy, komunikacji interpersonalnej, odpowiedzialności i autonomii (Jastrzębska, 2011: 193-197). Są swoistą globalną strategią edukacji twórczej, o której warto pamiętać, przygotowując przyszłych nauczycieli języków obcych do twórczości pedagogicznej.

\section{BIBLIOGRAFIA}

Coiduras, J.L. i Carrera X. 2010. „La construction du sens autour de la notion de la compétence dans des dispositifs universitaires". Éducation et francophonie XXXVIII-2. 96-112. (http://www.acelf.ca/c/revue/pdf/EF-38-2-completweb.pdf) [DW: 15.08.2012].

Correa Molina, E., Collin, S., Chaubert Ph. i Gervais, C. 2010. „Concept de réflexion : un regard critique". Éducation et francophonie, XXXVIII-2. 135-152. (http://www.acelf.ca/c/revue/pdf/EF-38-2-completweb.pdf) [DW : 15.08.2012].

Cusson, P. 1993. La créativité à l'ordre du jour. Québec: Louise Courteau Editrice.

Dawid, J.Wł. 1932. O duszy nauczycielstwa. Warszawa: Nasza Księgarnia, Sp. akcyjna Związku Nauczycielstwa Polskiego.

Dylak, S. 2010. „Kształtowanie (się) pedagogicznej wiedzy nauczycielskiej w procesie stawania się i bycia nauczycielem - epitafium". [w:] Piekarski, J., Urbaniak-Zając,

\footnotetext{
${ }^{9}$ Skrót nazwy: twórcze rozwiqzywanie problemów.
} 
D. i Szmidt, K.J. (red.). Metodologiczne problemy tworzenia wiedzy w pedagogice. Oblicza akademickiej praktyki. Kraków: Oficyna Wydawnicza „Impuls”. 63-76.

Ekiert-Oldroyd, D. 2003. „Pedeutologiczne aspekty dydaktyki twórczości i ich pragmatyczne implikacje". [w:] Szmidt, K.J. (red.). Dydaktyka twórczości Kraków: Oficyna Wydawnicza"Impuls". 135-158.

Gaś, Z. B. 2001. Doskonalqacy się nauczyciel. Lublin: Wydawnictwo Uniwersytetu Marii Curie- Skłodowskiej.

Gnitecki, J. 2002. „Kompetencje i zwiększanie szans edukacyjnych nauczycieli w cyklu życia w warunkach postępującej globalizacji”. [w:] Kozioł, E. i Kobyłecka, E. (red.) W poszukiwaniu wyznaczników nauczyciela XXI wieku. Zielona Góra: Wydawnictwo UZ. 53-75.

Guilford, J. P. 1978. Natura inteligencji człowieka. Warszawa: PWN.

Jastrzębska, E. 2009. „O edukacji twórczej nauczycieli raz jeszcze”. [w:] Pawlak, M., Mystkowska-Wiertelak, A. i Pietrzykowska, A. (red.). Nauczyciel języków obcych dziś i jutro. Poznań- Kalisz: Wydział Pedagogiczno-Artystyczny. 189-197.

Jastrzębska, E. 2011. Strategie psychodydaktyki twórczości w kształceniu językowym (na przykładzie języka francuskiego). Kraków: Oficyna Wydawnicza „Impuls”.

Koć-Seniuch, G. 2003. „Profesjonalizacja w kształceniu nauczycieli”. [w:] EkiertOldroyd, D. (red.). Problemy współczesnej pedeutologii. Teoria-praktykaperspektywy. Katowice: Wydawnictwo Uniwersytetu Śląskiego. 90-107.

Kwaśnica, R. 2003. „Być nauczycielem - wprowadzenie do myślenia”.[w:] Kwieciński, Z. i Śliwerski, B. (red.).Pedagogika, Podręcznik akademicki. Warszawa: Wyd. PWN: t. II. 293-315.

Kwiatkowska, H. 2008. Pedeutologia. Warszawa: WAiP.

Kupisiewicz, Cz. 2006. Szkoła XX w. Kierunki i próby przebudowy. Warszawa: PWN.

Le Boterf. G. 1994. De la compétence. Essai sur un attracteur étrange. Paris: Édition d'Organisation.

Lewowicki, T. 2007. Problemy kształcenia i pracy nauczycieli. Warszawa-Radom: Państwowy Instytut Wydawniczy.

Łączyk, M. 2011. „Predylekcje do twórczości codziennej i osamotnienie młodzieży ramowy model teoretyczny i diagnoza stanu w obszarze zjawisk". [w:] Krasoń, K. (red.). Chowanna 36. Katowice: Wydawnictwo UŚ: tom 1. 227-243.

Łobocki, M. 2005. „W trosce o skuteczne kształcenie pedagogiczne nauczycieli”. [w:] Hörner, W. i Szymański, M.S. (red.). Nauczyciel i kształcenie nauczycieli. Zmiany i wyzwania. Warszawa: Wyd. Akademickie „Żak”. 92-102.

Modrzejewska-Świgulska, M. 2009. „Badanie twórczości codziennej - perspektywa biograficzna". [w:] Szmidt, K.J. (red.). Metody pedagogicznych badań nad twórczościq. Teoria i empiria. Łódź: Wyd. Akademii HumanistycznoEkonomicznej. 147-219.

Nęcka, E. i in. 2005. Trening twórczości. Gdańsk: GWP.

Okoń, W. 2009. Wszystko o wychowaniu. Warszawa: Wyd. Akademickie "Żak".

Palka, S. 2003. Pedagogika w stanie tworzenia. Kraków: Wydawnictwo Uniwersytetu Jagiellońskiego. 
Perrenoud, Ph.1999. Enseigner: agir dans l'urgence décider dans l'incertitude. Paris: ESF éditeur.

Petkowicz, A. 2005. „Wybrane aspekty twórczości nauczycieli gimnazjum”. [w:] Pęczkowski, R. (red.) Polski system edukacji po reformie. 3 stan, perspektywy, zagrożenia). Poznań-Warszawa: Dom Wydawniczy Elipsa. 200-208.

Richer, J.-J. 2011. „De l'enseignant de langue(s) au professionnel des langues”. Etudes de linguistique appliquée 161. Paris: Didier Erudition Klincksieck. 63-77.

Sajdak, A. 2008. Edukacja kreatywna. Kraków: Wyd. WAM.

Schulz, R. 1996. Studia z innowatyki pedagogicznej. Toruń: Wyd. Uniwersytetu Mikołaja Kopernika.

Sikora, J. 2009. „Przygotowanie przyszłych nauczycieli w pełnieniu ról zawodowych”. [w:] Korzeniowski, W., Murzyn, A. i Szuścik, U. (red.). Sztuka bycia uczniem i nauczycielem. Kraków: Oficyna Wydawnicza „Impuls”. 130-134.

Stankiewicz, R. 2002. „Oczekiwania pedeutologów wobec nauczycieli w różnych okresach dziejów wychowania i ich uwarunkowania". [w:] Kozioł, E. i Kobyłecka, E. (red.) W poszukiwaniu wyznaczników nauczyciela XXI wieku. Zielona Góra: Wydawnictwo UZ. 17-34.

Szmidt, K. J. 2001. Szkice do pedagogiki twórczości. Kraków: Oficyna Wydawnicza „Impuls”.

Szmidt, K. J.(red.). 2003. Dydaktyka twórczości. Kraków: Oficyna Wydawnicza „Impuls.”

Szmidt, K. J. 2004. „Edukacja według Torrance’a”. Teraźniejszość- Człowiek- Edukacja, 4. Wrocław: Wydaw. Naukowe Dolnośląskiej Szkoły Wyższej Edukacji TWP. 27-45.

Szmidt, K. J. (red.) 2005. Trening twórczości w szkole wyższej. Łódź: Wydawnictwo WSH-E.

Szmidt, K. J. 2007. Pedagogika twórczości. Gdańsk: GWP.

Szmidt, K. J. (red.) 2008. Trening kreatywności. Gliwice: Wydawnictwo Helion.

Targońska, J. 2009. „Wiedza czy umiejętności? Czego potrzebuje dobry nauczyciel?” [w:] Pawlak, M., Mystkowska-Wiertelak, A. i Pietrzykowska, A. (red.). Nauczyciel języków obcych dziś i jutro. Poznań-Kalisz: Wydział Pedagogiczno- Artystyczny. 11-25.

Wilczyńska, W. 2009. „Nauczyciel języka obcego jako badacz”. [w:] Pawlak, M., Mystkowska-Wiertelak, A. i Pietrzykowska, A. (red.). Nauczyciel języków obcych dziś i jutro. Poznań- Kalisz: Wydział Pedagogiczno- Artystyczny. 493-508.

Wróblewska, M. 2011. „Rozwój przez nabywanie kompetencji (w aspekcie uwarunkowań aktywności twórczej)". [w:] Krasoń, K. (red.). Chowanna 36. Katowice: Wydawnictwo UŚ: tom 1. 59-69.

Zawadzka, E. 2004. Nauczyciel języków obcych w dobie przemian. Kraków: Oficyna Wydawnicza „Impuls”. 